\title{
FGF13 Gene
}

National Cancer Institute

\section{Source}

National Cancer Institute. FGF13 Gene. NCI Thesaurus. Code C118513.

This gene plays a role in neural development. 